Jpn. J. Phys. Fitness Sports Med. 1998, $47: 421 \sim 426$

\title{
A SINGLE BOUT OF EXERCISE INDUCES A TRANSIENT ALTERATION IN GENE EXPRESSION OF THE INSULIN SIGNALING PATHWAY
}

\author{
Takatoshi Inoue $*$, Young-Bum Kim**, Rieko NaKajima***, Toyoko Sekine****, \\ Kumpei TOKUYAma $* *$ and MaSAShige SUZUKI $* * *$
}

\begin{abstract}
The present study was conducted to examine whether gene expression of the insulin signaling pathway is activated in response to a single bout of exercise. Adult male rats underwent a single bout of treadmill exercise for $90 \mathrm{~min}$ at $22 \mathrm{~m} / \mathrm{min}$ on a $6{ }^{\circ} \mathrm{C}$ incline. The animals were sacrificed immediately after exercise or after a predetermined post-exercise recovery period of up to $48 \mathrm{~h}$, and the level of mRNA in the gastrocnemius muscle was measured by the RT-PCR method. Immediately after exercise, mRNA levels of insulin signal transduction intermediates in the gastrocnemius muscle were lower in the exercise group than in the controls. Following this tendency reduction, mRNA levels of insulin receptor, IRS-1, PI 3-kinase, SH-PTP2 and Nck were higher in the exercise group than in the controls. The levels of PI 3-kinase mRNA was significantly higher in the exercise group than in the controls within $6 \mathrm{~h}$ after exercise, while levels of mRNA for insulin receptor. IRS-1, SH-PTP2 and Nck were significantly higher in the the exercise group than in the controls at $48 \mathrm{~h}$ after exercise. Gene expression of oncogenes was also affected by a single bout of exercise. Levels of $c$-fos and c-myc mRNA were significantly higher than in the controls immediately after exercise, while the level of c-jun mRNA was lower in the exercise group at $3 \mathrm{~h}$ after exercise. Thus, a single bout of exercise affects the gene expression of insulin signal transduction pathway intermediates and oncogenes in rat gastrocnemius muscle. The present findings suggest that an exercise-induced adaptive increase of skeletal muscle insulin sensitivity is a cumulative effect of a single bout of exercise on the gene expression of insulin signal transduction pathway intermediates.
\end{abstract}

(Jpn. J. Phys. Fitness Sports Med. 1998, $47: 421 \sim 426$ )

key words : mRNA, oncogene, insulin sensitivity, insulin signaling pathway, exercise

Endurance training has been reported to enhance insulin sensitivity with increasing insulin receptor number in skeletal muscle ${ }^{1-5)}$. Enhanced gene expression of post receptor insulin signal transduction pathway may also contribute to increased insulin sensitivity of endurance trained skeletal muscle, since mRNA levels of insulin receptor, insulin receptor substrate-1 (IRS-1) ${ }^{6}$, phosphatidylinositol 3-kinase (PI3-kinase) ${ }^{7)}$ and GLUT4 ${ }^{8.9)}$ were increased in skeletal muscle of endurance trained rats. Increase in gene expression of GLUT4 was detected $16 \mathrm{~h}$ after one pro- longed exercise session ${ }^{10)}$, suggesting that enhanced gene expression observed in trained skeletal muscle reflects an effect of a single bout of exercise.

Insulin elicits normal cellular effects by first binding to receptor, resulting in activation of the receptor tyrosine kinase. Activated insulin receptor tyrosine kinase causes tyrosine phosphorylation of IRS-1. Phosphorylated IRS-1 subsequently binds cytoplasmic signaling proteins containing SH2 domains, such as PI 3-kinase, GRB2, Nck and SH-PTP2. GRB2 transmits insulin signal on the
*呉共済病院臨床スポーツ科 テ737-0811 遣市西中央2-3-28

**ハーパード大学医学部ベスイスラエル病院 ボストン・マサチューセッチ州, 米国

$* * *$ 筑波大学体育科学系 テ305-0006 つくば市天王台1-1-1

*****国立健康・栄養研究所 テ 162-0052 新宿区戸山1-23-1
Kure Kyousai Hospital, Kure, Hiroshima, Japan 737-0811

Beth Iserael Hospital and Harvard Medical School, Boston, MA02215

Instiute of Health \& Sport Sciences, University of Tsukuba, Ibaraki, Japan 305-0006

National Institute of Health \& Nutrition, Tokyo, Japan 162-0052 
receptor to ras complex and MAP kinase pathway ${ }^{11,12)}$. In addition to gene expression of insulin receptor, that of IRS-1, PI3-kinase, Nck, GRB2, SH-PTP2, ras and GLUT4 are also affected in endurance trained skeletal muscle although physiological function of some of these signaling molecules is less well known ${ }^{7)}$.

Effect of a single bout of exercise on gene expression is transient. For example, gene expression of hexokinase in rat skeletal muscle increased $8 \mathrm{~h}$ after a single bout of exercise but returned to basal level by $24 \mathrm{~h}^{13)}$. One prolonged exercise session increased gene expression of GLUT4 within $16 \mathrm{~h}$ but a time course of the change in gene expression after an exercise session has not been studied $^{10)}$. In this study, we examined a time course of changes in gene expression of insulin signal transduction pathway intermediates in rat gastrocnemius muscle during $48 \mathrm{~h}$ after a single bout of exercise.

\section{METHODS}

Animal care. Sixty male Sprague-Dawley rats (6 week old) were obtained from CLEA Japan, Tokyo. All procedures involving animals were approved by the experimental animal care committee of University of Tsukuba. The rats were. housed at $22^{\circ} \mathrm{C}$ with light from $7: 00$ to $19: 00 \mathrm{~h}$ and with free access to water and food (CE-2, CLEA Japan, Tokyo). To familiarize the animals with the motor-driven treadmill (model III : Autome Kogyo, Tokyo) ${ }^{14)}$, all animals were exercised for 10 minutes daily for 4 days.

Experimental procedures. The exercise protocol employed in the present study was based on the work of O'Doherty et al. ${ }^{13)}$. Rats undertook a single bout of treadmill exercise for $90 \mathrm{~min}$ at 22 $\mathrm{m} / \mathrm{min}$ on $6^{\circ}$ incline. Animals were sacrificed by decapitation before (control value), immediately, $3,6,9,12,24$ or $48 \mathrm{~h}$ after exercise. Gastrocnemius muscle was immediately removed, freeze-
Tabie 1. Sequences of PCR primers.

\begin{tabular}{|c|c|c|c|}
\hline Gene & $\begin{array}{l}\text { Nucleotide } \\
\text { number }\end{array}$ & $\begin{array}{l}\text { Size of PCR } \\
\text { product (bp) }\end{array}$ & $\begin{array}{c}\text { GenBank } \\
\text { accession no. }\end{array}$ \\
\hline \multirow[t]{2}{*}{ Insulin receptor } & $2474-2493$ & 270,234 & M 29014 \\
\hline & $2743-2724$ & & \\
\hline \multirow[t]{2}{*}{ IRS-1 } & $1382-1401$ & 337 & X 58375 \\
\hline & $1718-1699$ & & \\
\hline \multirow[t]{2}{*}{ Shc } & $1-24$ & 416 & D 83015 \\
\hline & $416-383$ & & \\
\hline \multirow[t]{2}{*}{ SH-PTP 2} & $1-24$ & 449 & D 83016 \\
\hline & $449-426$ & & \\
\hline \multirow[t]{2}{*}{ GRB 2} & $191-214$ & 477 & $\mathrm{X} 62853$ \\
\hline & $667-644$ & & \\
\hline \multirow[t]{2}{*}{ Nck } & $21-44$ & 251 & H 32835 \\
\hline & $251-228$ & & \\
\hline \multirow[t]{2}{*}{ PI 3-kinase } & $1297-1382$ & 231 & M 61904. M 61746 \\
\hline & $1527-1504$ & & \\
\hline \multirow[t]{2}{*}{ GLUT 4} & $221-240$ & 393 & X 14771 \\
\hline & $613-594$ & & \\
\hline \multirow[t]{2}{*}{ ERK 1} & $499-518$ & 260 & M 61177 \\
\hline & $758-739$ & & \\
\hline \multirow[t]{2}{*}{ ERK 2} & $234-253$ & 297 & M 64300 \\
\hline & $530-511$ & & \\
\hline \multirow[t]{2}{*}{ B-Actin } & $2846-2865$ & 377 & $\mathrm{~J} 00691$ \\
\hline & $3222-3203$ & & \\
\hline
\end{tabular}

Sequences of each primer pair and their location in sequences cited in GenBank database are noted.

clamped at liquid nitrogen temperature, and stored at $-80^{\circ} \mathrm{C}$ until use. Body weight of animals at the time of sacrifice ranged from $200 \sim 260 \mathrm{~g}$ and it was not different among the groups.

Analytical methods. Total RNA was extracted from skeletal muscle with a guanidium thiocynate water-saturated phenol extraction method ${ }^{15)}$. First-strand cDNA synthesis was performed on 5 $\mu \mathrm{g}$ total RNA using oligo (dT) as described by manufacturer's instructions (BRL SuperScript Kit, Life Technologies). The sequences of the primers $^{16 \sim 19)}$ used for amplification are shown in Table 1. Before PCR amplification, the primers were labeled with $\gamma-\left[{ }^{32} \mathrm{P}\right]$ ATP (Amersham) by using T4 polynucleotide kinase (Takara, Tokyo, Japan). PCR reactions were carried out in a DNA Thermal Cycler (Perkin-Elmer, Cetus) using the 
following cycle conditions: initial denaturation at $94^{\circ} \mathrm{C}$ for $6 \mathrm{~min}$, denaturation at $94^{\circ} \mathrm{C}$ for $1 \mathrm{~min}$, annealing at $60^{\circ} \mathrm{C}$ for $2 \mathrm{~min}$ and extension at $72^{\circ} \mathrm{C}$ for $3 \mathrm{~min}^{20)}$. As an exception, annealing at $63^{\circ} \mathrm{C}$ for PI 3-kinase, $55^{\circ} \mathrm{C}$ for oncogenes and $58^{\circ} \mathrm{C}$ for $\beta$-actin. There were 25 cycles for insulin receptor IRS-1, Nck, SH-PTP2 and oncogenes, 23 cycles for PI 3-kinase and GRB2, 22 cycles for MAP kinase isoforms (ERK1, ERK2) and GLUT4 and 18 cycles for $\beta$-actin. PCR products $(10 \mu \mathrm{l})$ were analyzed by electrophoresis in $7.5 \%$ polyacrylamide gels. The amounts of mRNA in each sample were quantitated by a laser image analyzer (Fujix BAS2000, Fuji Film). The PCR cycles and imaging plate times were kept within their respective exponential and linear range.

Statistics. Changes in mRNA levels after the exercise are expressed as \% of control value. Values shown are means $\pm \mathrm{SE}$. Comparison of the mean values was performed with one-way ANO. VA with a post hoc Dunnett's test. Differences were considered to be statistically significant at $\mathrm{P}<0.05$

\section{RESULTS}

Immediately after a single bout of exercise, mRNA levels of all insulin signal transduction pathway intermediates were lower than the control values and the difference in insulin receptor and SH-PTP2 mRNA was statistically significant.
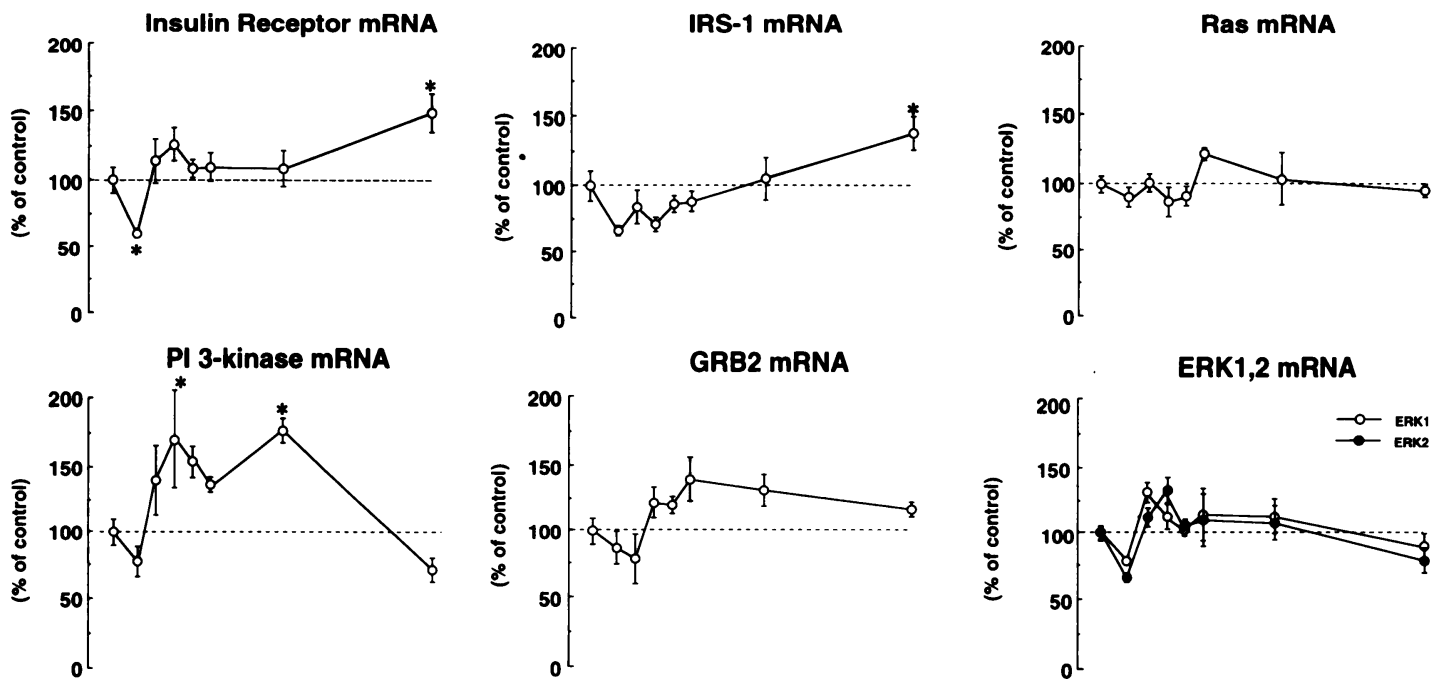

ERK1,2 MRNA
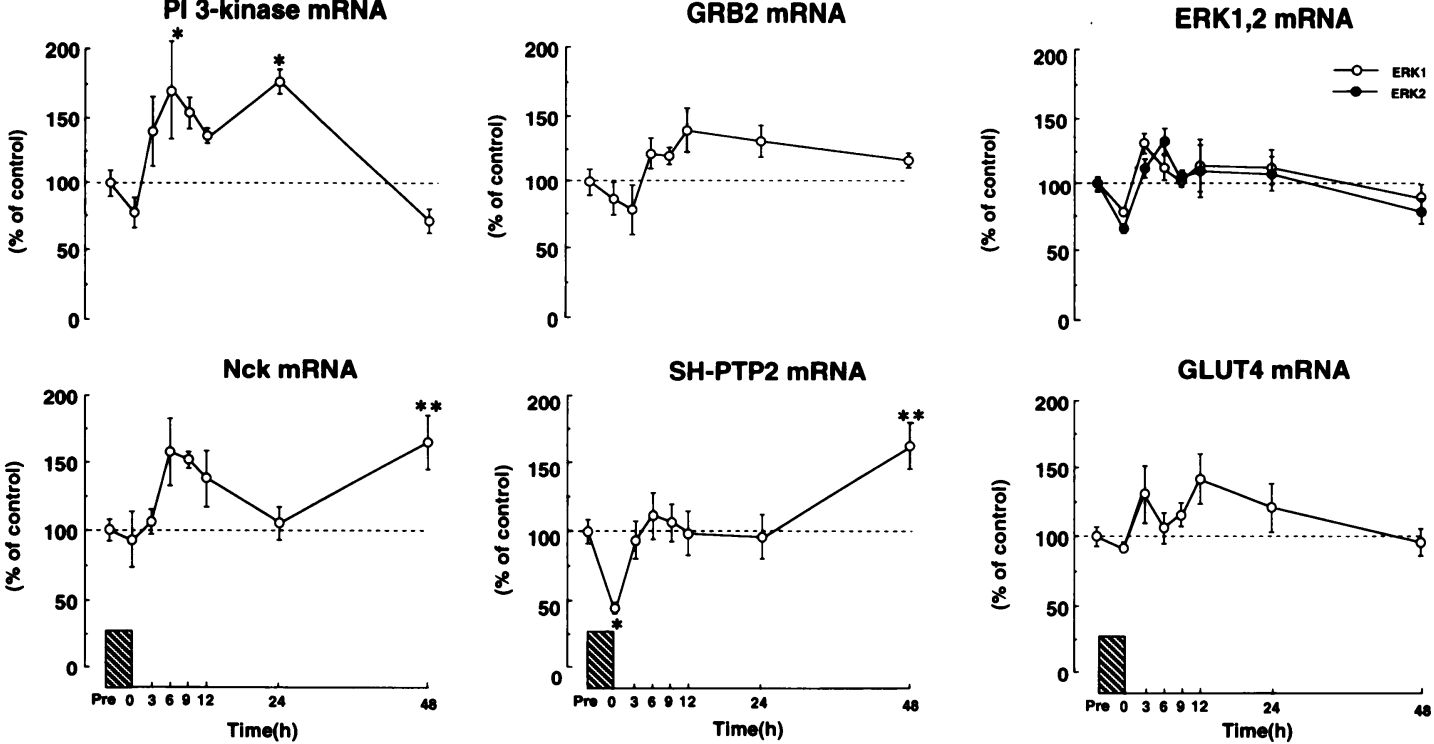

GLUT4 mRNA

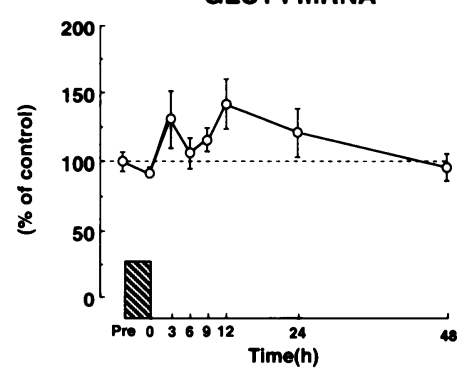

Fig. 1. Time course of changes in mRNA levels of insulin signal transduction intermediates in gastrocnemius muscle after $90 \mathrm{~min}$ of exercise $(\mathbf{N})$. Values are mean $\pm \mathrm{SE} .{ }^{*} \mathrm{P}<0.05$ and ${ }^{* *} \mathrm{P}<0.01$ (statistical ignificance from initial value). 
Following this lowering change, mRNA levels, of insulin receptor, IRS-1, PI 3-kinase, SH-PTP2 and Nck were higher in exercise group than those in the control during the $48 \mathrm{~h}$ after the cessation of exercise. Changes in mRNA levels of GRB2, ras, ERK1, ERK2 and GLUT4 were not statistically significant (Fig. 1).

Gene expression of oncogenes was also affected by a single bout of exercise. mRNA levels of $c$-fos and $c--m y c$ were significantly higher than those in the control immediately after exercise, and the increase in $c$-fos was still statistically significant at 3 and $12 \mathrm{~h}$ after exercise. Conversely, mRNA level of $c$-jun was lower in exercise group than those in the control at 3 and $6 \mathrm{~h}$ after exercise (Fig. 2). Gene expression of $\beta$-actin was not affected by exercise (data not shown).

\section{immediate early gene mRNA}

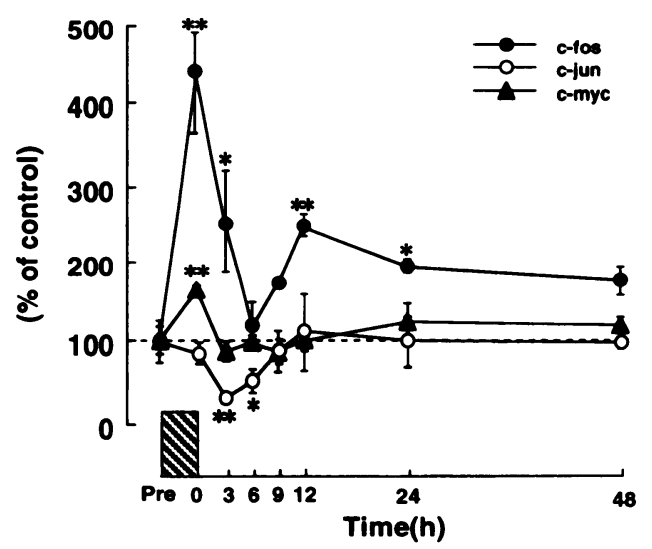

Fig. 2. Time course of changes in mRNA levels of oncegenes in gastrocnemius muscle after $90 \mathrm{~min}$ of exercise $(\mathbf{N})$. Values are mean $\pm \mathrm{SE} .{ }^{*} \mathrm{P}<0.05$ and ${ }^{* *} \mathrm{P}<0.01$ (statistical ignificance from initial value).

\section{DISCUSSION}

The novel finding from this study is that a single bout of exercise elicits increase in gene expression of insulin signal transduction intermediates in rat gastrocnemius muscle. mRNA levels of insulin receptor, IRS-1 and SH2 domain containing signal molecules that interact with IRS-1 (PI 3-kinase, SH-PTP2, Nck) increased during the $48 \mathrm{~h}$ after the exercise (Fig. 1). Physiological significance of this finding could be related to not only an acute but also a chronic effect of endurance exercise on insulin sensitivity. Enhanced mRNA levels of insulin receptor, IRS-1, PI 3-kinase and ras were also observed in endur. ance trained skeletal muscle ${ }^{7)}$. The transient changes in mRNA level of insulin signal transduction intermediates, such as insulin receptor, IRS-1, PI 3-kinase, Nck and SH-PTP2, after a single bout of exercise did not complete within $24 \mathrm{~h}$. Present results suggest the possibility that enhanced gene expression observed in trained skeletal muscle reflects a cumulative effect of a single bout of exercise. MAP kinase pathway is suggested to be involved in regulation of gene transcription, protein synthesis, glycogen metabolism and glucose transport ${ }^{11.12)}$. Recent study demonstrated that MAP kinase isoforms (ERK1, 2) were activated immediately after a single bout of exercise ${ }^{21)}$ but gene expression of ERK1, 2 was not affected under our experimental condition. Altered gene expression of Nck, SH-PTP2 and GRB2 was also found in adipose tissue and liver of diabetic animals $^{22.23)}$, but physiological significance of these alterations remains to be elucidated.

Enhanced gene expression of GLUT4 was detected at $16 \mathrm{~h}$ after a single bout of exhaustive swimming lasting $6 \mathrm{~h}^{10)}$, In the present experiment, mRNA level of GLUT4 increased $12 \mathrm{~h}$ after cessation of exercise although the increase was not statistically significant and our result is therefore consistent with the previous report which examined GLUT 4 gene expression at 3,8 and 24 $\mathrm{h}$ after a single bout of treadmill running lasting $90 \mathrm{~min}^{13)}$. Failure to detect a significant increase in GLUT4 gene expression after a single bout of exercise can be explained by the difference in 
experimental conditions such as type and duration of exercise.

An increase in mRNA levels of insulin receptor, IRS-1, Nck and SH-PTP2 were first detected at 48 $\mathrm{h}$ while that of PI3-kinase was already detected within $24 \mathrm{~h}$ after exercise, suggesting different mechanisms of exercise to modify gene expression. Since the increase in gene expression of insulin signal transduction pathway was preceded by a transient decrease in gene expression immediately after exercise, it is likely that exercise itself does not directly elicit upregulation of the genes. Insulin receptor and IRS-1 gene possess responsive elements for AP-1 complex, consisted with $c-f o s$ and $c-j u n$, in their promoter region and gene expression of these immediate early genes in skeletal muscle is enhanced by a combination of stretch and electrical stimulation ${ }^{24,25)}$. Considering available knowledge of their physiological function, it was conceivable that oncogene products, as AP-1 transcriptional factor might mediate the effect of a single bout of exercise to stimulate gene expression of insulin signal transduction pathway. Consistent with the observation after in situ electrical stimulation, a single bout of exhaustive running enhanced gene expression of $c$-fos and $c-m y c$ immediately after exercise but decreased $c$-jun expression. Thus changes in expression of oncogenes preceded the increase in gene expression of insulin signal transduction pathway, but the physiological role of oncogene products as a transcriptional factor for gene expression of insulin signal transduction pathway remained to be clarified.

Thus a single bout of exercise affects gene expression of insulin signal transduction pathway intermediates and oncogenes in rat gastrocnemius muscle. It is conceivable that the effect of a single bout of exercise to increase mRNAs of insulin signal transduction pathway intermediates accumulates and results in enhanced insulin sensitivity in trained skeletal muscle.

(Accepted Apr. 22, 1998)

\section{REFERENCES}

1) Bonen, A., P. A. Clun, and M. H. Tan. Chronic exercise increases insulin binding in muscles but not liver. Am. J. Physiol. 251 (Endocrinol. Metab. 14) : E196-E203, 1986.

2) Dohm, G. L., M. K. Sinha, and J. F. Caro. Insulin receptor binding and protein kinase activity in muscles of trained rats. Am. J. Physiol. 252 (Endocrinol. Metab. 15) : E170-E175, 1987.

3) Horton, S. E. Exercise and physical training : effects on insulin sensitivity and glucose metabolism. Diabetes Metabolism Reviews 2: 1-17, 1986

4) Koivisto, V. A., H. Yki-Jävinen, and R. A. DeFronzo. Physical training and insulin sensitivity. Diabetes Metabolism Reviews 1 : 445-481, 1986.

5) Santos, R. F., C. E. Mondon, G. M. Reaven, and S. Azhar. Effect of exercise training in the relationship between insulin binding and insulin-stimulated tyrosine kinase activity in rat skeletal muscle. Metabolism 38 : 376-386, 1989.

6) Kim, Y., T. Inoue, R. Nakajima, K. Nakae, T. Tamura, K. Tokuyama, and M. Suzuki. Effect of endurance training on gene expression of insulin signal transduction pathway. Biochem. Biophys. Res. Commun. 210 : 766-773, 1995.

7) Kim, Y., T. Inoue, R. Nakajima, K. Tokuyama, and M. Suzuki. Endurance training modurates gene expression of insulin signaling pathway intermediates in skeletal muscle. Diabetes 45 supple 2:340A, 1996.

8) Ploug, T., B. M. Stallknecht, O. Pedersen, B. B. Kahn, T. Ohkuwa, J. Vinten, and H. Galbo. Effect of endurance training on glucose transport capacity and glucose transporter expression in rat skeletal muscle. Am. J. Physiol. 259 (Endocrinol. Metab. 22) : E778-E786, 1990.

9) Rodnick, K. J., E. J. Henriksen, D. E. James, and J. O. Holloszy. Exercise training, glucose transporters, and glucose transport in rat skeletal muscles. Am. J. Physiol. 262 (Cell Physiol. 31) : C9-C14, 1992.

10) Ren, J. M., C. F. Semenkovich, E. A. Gulve, J. Gao, and J. O. Holloszy. Exercise induces rapid increases in GLUT4 expression, glucose transport capacity, and insulin-stimulated glycogen storage in muscle. J. Biol. Chem. 269 : 14396-14401, 1994.

11) Cheatham, B., and C. R. Kahn. Insulin action and the insulin signaling network. Endocrine Reviews 16 : 117-142, 1995.

12) Kahn, C. R. Insulin action, diabetogenes, and the cause of type II diabetes. Diabetes $43: 1066-1084$, 1994.

13) O'Doherty, R. M., D. P. Bracy, H. Osawa, D. H. Wasserman, and D. K. Granner. Rat skeletal muscle 
hexokinase II mRNA and activity are increased by a single bout of acute exercise. Am.J.Physiol. 266 (Endocrinol. Metab. 29) : E171-E178, 1994.

14) Murakami, T., Y. Shimomura, N. Fujitsuka, N. Nakai, S. Sugiyama, T. Ozawa, M. Sokabe, S. Horai, K. Tokuyama, and M. Suzuki. Enzymatic and genetic adaptation of soleus muscle mitochondria to physical training in rats. Am. J. Physiol. 267 (Endocrinol. Metab. 30) : E388-E395, 1994.

15) Chomczynski, P., and N. Sacchi. Single-step method of RNA isolation by acid guanidinium thiocynatephenol-chloroform extraction. Anal. Biochem. 162 : 156-159, 1987

16) Boulton, T. G., S. H. Nye, D. J. Robbins, N. Y. Ip, E. Radziejewska, S. D. Morgenbesser, R. A. DePinho, N. Panayotatos, M. H. Cobb, and G. D. Yancopoulos. ERKs : a family of protein-serine/threonine kinases that are activated and tyrosine phosphorylated in response to insulin and NGF. Cell $65: 663-675$, 1991.

17) Goldstein, B. J., and A. L. Dudley. The rat insulin receptor:primary structure and conservation of tissue-specific alternative messenger RNA splicing. Mol. Endocrinol. 4 : 235-244, 1990.

18) Nudel, U., R. Zakut, M. Shani, S. Neuman, Z. Levy, and $D$. Yaffe. The nucleotide sequence of the rat cytoplasmic beta-actin gene. Nucleic Acids Res 11 : 1759-1771, 1983.

19) Sun, X. J., P. Rothenberg, C. R. Kahn, J. M. Backer, E. Araki, P. A. Wilden, D. A. Cahill, B. J. Goldstein, and M. F. White. Structure of the insulin receptor substrate IRS-1 defines a unique signal transduction protein. Nature 352 : 73-77, 1991.

20) Kim, Y., T. Tamura, S. Iwashita, K. Tokuyama, and M. Suzuki. Effect of high-fat diet on gene expression of Glut 4 and insulin receptor in soleus muscle. Biochem. Biophys. Res. Commun. 202 : 519-526. 1994.

21) Goodyear, L. J., P.-Y. Chang, D. J. Sherwood, S. D. Dufresne, and D. E. Moller. Effects of exercise and insulin on mitogen-activated protein kinase signaling pathways in rat skeletal muscle. Am. J. Physiol. 271 (Endocrinol. Metab. 34) : E403-E408, 1996.

22) Bonini, J. A., J. R. Colca, and C. Hofmann. Altered expression of insulin signaling components in streptozotocin-treated rats. Biochem.Biophys. Res. Commun. 212 : 933-938, 1995.

23) Bonini, J. A., J. R. Colca , C. Dailey, M. White, and C. Hofmann. Compensatory alteration for insulin signal transduction and glucose transport in insulin-resistant diabetes. Am. J. Physiol. 269 (Endocrinol. Metab. 32) : E759-E765, 1995.

24) Goldspink, D. F., V. M. Cox, S. K. Smith, L. A. Eaves, N. J. Osbaldeston, D. M. Lee, and D. Mantle. Muscle growth in response to mechanical stimuli. Am. J. Physiol. 268 (Endocrinol. Metab. 31) : E288E297, 1995.

25) Michel, J. B., G. A. Ordway, J. A. Richardson, and R. S. Williams. Biphasic induction of immediate early gene expression accompanies activity-dependent angiogenesis and myofiber remodeling of rabbit skeletal muscle. J. Clin. Invest. 94 : 277-285, 1994. 